\title{
Emergence of the aerobic biosphere during the Archean-Proterozoic transition: Challenges of future research
}

\begin{abstract}
Victor A. Melezhik, Geological Survey of Norway, Leiv Eirikssons vei 39, 7491 Trondheim, Norway; Anthony E. Fallick, Scottish Universities Environmental Research Centre, Rankine Avenue, East Kilbride, Glasgow G75 OQF, Scotland; Eero J. Hanski, University of Oulu, Linnanmaa, 90014 Oulu, Finland; Lee R. Kump*, Dept. of Geosciences, Pennsylvania State University, 535 Deike Bldg, University Park, Pennsylvania 16802, USA; Aivo Lepland, Geological Survey of Norway, Leiv Eirikssons vei 39, 7491 Trondheim, Norway; Anthony R. Prave, University of St. Andrews, St. Andrews, Fife KY16 9AL, Scotland; Harald Strauss, Westfälische Wilhelms-Universität Münster, Corrensstraße 24, 48149 Münster, Germany
\end{abstract}

\begin{abstract}
The earth system experienced a series of fundamental upheavals throughout the Archean-Paleoproterozoic transition (ca. 2500-2000 Ma). Most important were the establishment of an oxygen-rich atmosphere and the emergence of an aerobic biosphere. Fennoscandia provides a fairly complete record of the hallmark events of that transition: widespread igneous activity, its association with a possible upper-mantle oxidizing event, the global Huronian glaciation, a rise in atmospheric oxygen, the protracted and large-magnitude Lomagundi-Jatuli carbon isotope excursion, a substantial increase in the seawater sulfate reservoir, changes in the sulfur and phosphorus cycles, a radical modification in recycling of organic matter, and the Shunga Event-the accumulation of unprecedented organic-matter-rich sediments and the oldest known inferred generation of significant petroleum. Current research efforts are focused on providing an accurate temporal framework for these events and linking them into a coherent story of earth system evolution.
\end{abstract}

\section{INTRODUCTION}

The Archean (3800 Ma-2500 Ma) earth system functioned under an oxygen-poor atmosphere, and although oxygenrich habitats undoubtedly existed once cyanobacteria evolved and began producing oxygen (>2700 Ma; Summons et al., 1999; Brocks et al., 1999), these were restricted to microbial mats or perhaps ephemeral oxygen oases in the surface ocean or in lakes. During this time and the initial 500 m.y. of the Proterozoic, Earth's lithosphere underwent the assembly of two supercontinents: one, Kenorland, comprising the Laurentian, Fennoscandian, and Siberian shields; the other, the amalgamated Zimbabwe, Kaapvaal, Pilbara, Sao Francisco, and Indian cratons (Aspler and Chiarenzelli, 1998; Williams et al., 1991). Subsequent breakup involved the emplacement of voluminous continental flood basalts, giant radiating dike swarms and layered gabbro-norite intrusions (e.g., Heaman, 1997; Vogel et al., 1998), and deposition of banded iron formations (Pickard, 2003). Profound climatic and biogeochemical events also were occurring, such as icehouse conditions (Young et al., 2001; Evans, 2003), the rise in atmospheric oxygen levels (Bekker et al., 2004), and the largest and longest duration positive excursion of carbon isotopic composition of sedimentary carbonates (Lomagundi-Jatuli Event), which predated deposition of anomalously organic carbon-rich sediments forming giant petroleum fields (Shunga Event; both events are reviewed in Melezhik et al., 1999a, 1999b). It was out of this period of geological upheaval that the aerobic earth system began to emerge, with biogeochemical cycles in the oceans and on land using the highly energetic aerobic pathway. Note though that some workers suggest that deep marine basins and perhaps the global deep ocean itself were euxinic (rich in $\mathrm{H}_{2} \mathrm{~S}$ ) for much of the ensuing Proterozoic (Canfield, 1998; Anbar and Knoll, 2002; Poulton et al., 2004).

Here we present a synthesis of the hallmark features of the Archean-Paleoproterozoic transition in the Fennoscandian Shield (Fig. 1). It is representative of other shield areas and provides important insights into the biogeochemical evolution of the earth system.

\section{Early Paleoproterozoic Environmental Upheavals: Insight from the Fennoscandian Shield}

The Fennoscandian Shield comprises Archean, Paleoproterozoic, and Mesoproterozoic domains (Fig. 1). In particular, its eastern part is a composite of Late Archean granite-greenstone belts, Paleoproterozoic rifts, the ca. 1900 Ma Kola Orogen, and multiphase Svecofennian orogens. Paleoproterozoic sedimentary and volcanic successions reach a cumulative thickness of more than $20 \mathrm{~km}$ and contain a rich record of nearly $700 \mathrm{~m}$.y. of earth history. Two of the best-explored and best-mapped areas are the Pechenga greenstone belt and the Onega Basin (Fig. 1); both contain exceptionally well-developed and preserved volcano-sedimentary successions (Fig. 2) that span $>2505-1970 \mathrm{Ma}$ and record intracratonic rifting, global glaciation (Fig. 3A-3D), and other profound alterations of Earth's surface environments. The research that has been conducted in the past on these rocks provides a series of fascinating vignettes of geologic events, but age control is poor, based largely on whole-rock $\mathrm{Rb}-\mathrm{Sr}$ ages, and the linkages between these events are not well understood. The challenge for the future is to correlate Fennoscandian events with those recorded on other continents and to weave these observations into a coherent story of the emergence of the aerobic biosphere.

*Corresponding author: lkump@psu.edu 


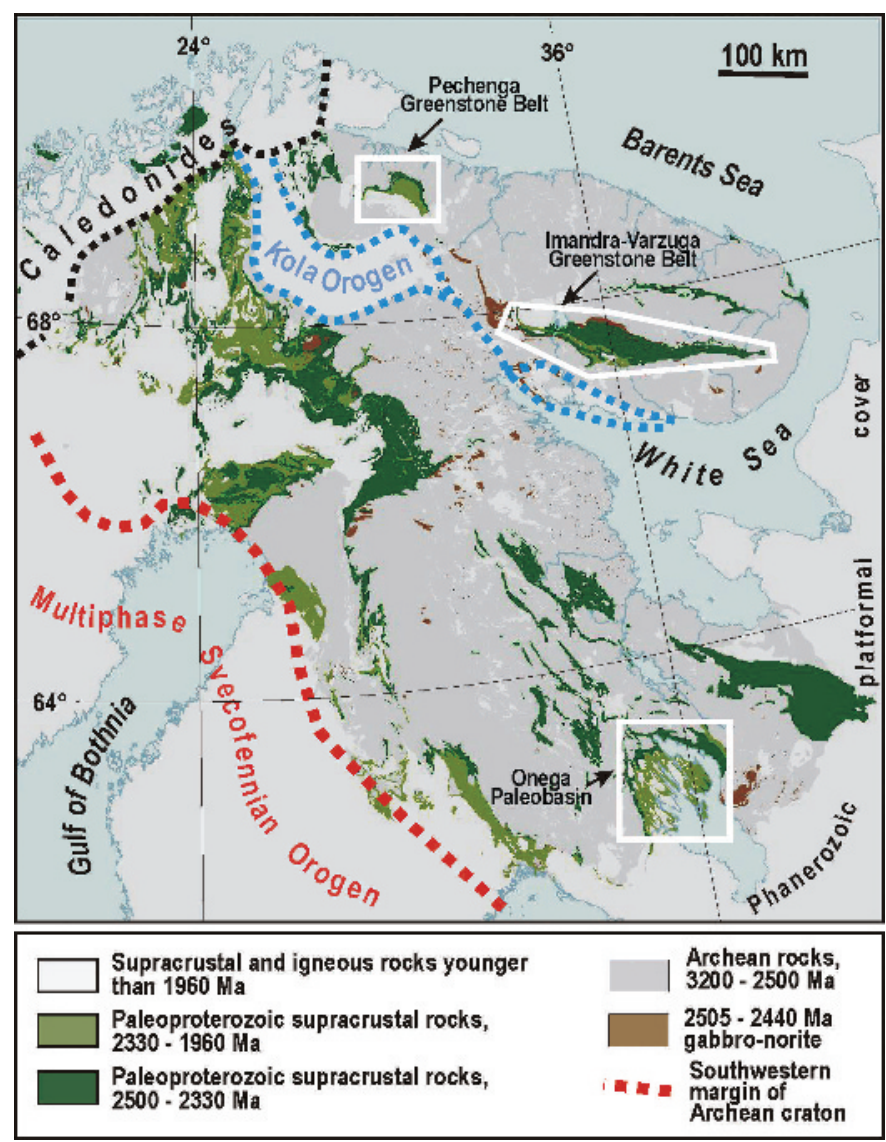

Figure 1. Simplified geological map of the Fennoscandian Shield.

\section{Huronian Glaciation}

The first significant environmental event known from the Archean-Paleoproterozoic transition is the seemingly rapid onset of global glaciations from otherwise climatically invariant conditions (Marmo and Ojakangas, 1984). The glaciation is known as the Huronian (after the eponymous Supergroup in Canada) and occurred at 2450-2220 Ma (Young et al., 2001). Some of the best age constraints come from South Africa where $2316 \pm 7$ Ma glacial diamictites (Hannah et al., 2004) rest unconformably on a variety of sedimentary rocks and banded iron formations (Bekker et al., 2001). Glaciogenic deposits of the Fennoscandian Shield are associated with the Sarioli Group and its equivalents (Marmo and Ojakangas, 1984) and consist of polymict conglomerates, sandstones, diamictites, and varve-like sedimentary rocks with dropstones (Fig. 3A and 3B).

The genesis of this global glaciation(s) remains poorly understood (Evans, 2003). Pavlov and Kasting (2002) linked the event to the collapse of an Archean methane-supported greenhouse effect driven by the rise of atmospheric oxygen (see below). Data from the Fennoscandian Shield and elsewhere suggest an alternative hypothesis involving a network of feedback loops as causative factors. At ca. $2500 \mathrm{Ma}$, mantle plume-driven continental uplifts emplaced voluminous continental flood-basalts (Heaman, 1997) in low latitudes (Mertanen et al., 1999). This global igneous event has otherwise been linked to mantle redox evolution and the rise of oxygen (Kump et al., 2001; see next section), but the weath-

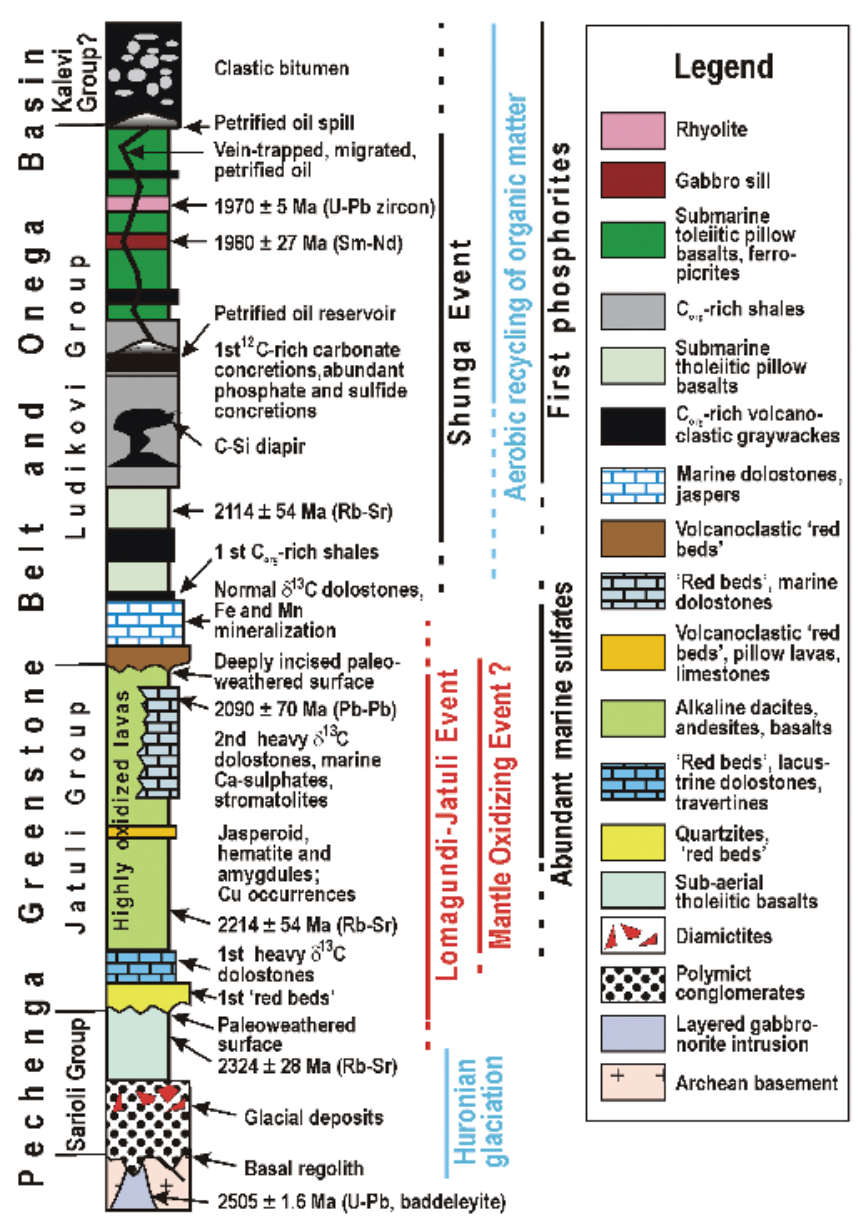

Figure 2. Composite ( 10,000-m-thick) Paleoproterozoic section for the Pechenga Greenstone Belt-Onega Basin linked to major environmental events. Radiometric dates are from Hanski (1992), Amelin et al. (1995), and Balashov (1996).

ering of the basalts could have driven the climate system into glaciation without these other feedbacks. The basalt flows subsequently were dissected by rifting, producing major topographic features and drainage patterns in all likelihood similar to those of younger continental flood-basalt provinces (Cox, 1989). This would have enabled deep, subaerial weathering lasting over tens of m.y. of extensive fresh basalt-covered areas and consequent intense consumption of atmospheric $\mathrm{CO}_{2}$ (Taylor and Lasaga, 1999; Dessert et al., 2001). Low ${ }^{87} \mathrm{Sr} /{ }^{86} \mathrm{Sr}$ ratios for this time interval (Bekker et al., 2003b) add credence to this scenario. Progressively diminishing volcanic $\mathrm{CO}_{2}$ emissions and a constant burial ratio of inorganic/organic carbon would have reduced atmospheric $\mathrm{CO}_{2}$ even further, all contributing to global cooling and the onset of icehouse conditions.

\section{The Great Oxidation Event (GOE)}

Interestingly, the igneous event in the earliest Paleoproterozoic may have been directly responsible for the rise in atmospheric oxygen content that occurred at this time. $S$ isotope data showing the disappearance of mass independent signatures in sedimentary sulfides provide compelling evidence for a substantial increase in atmospheric oxygen 

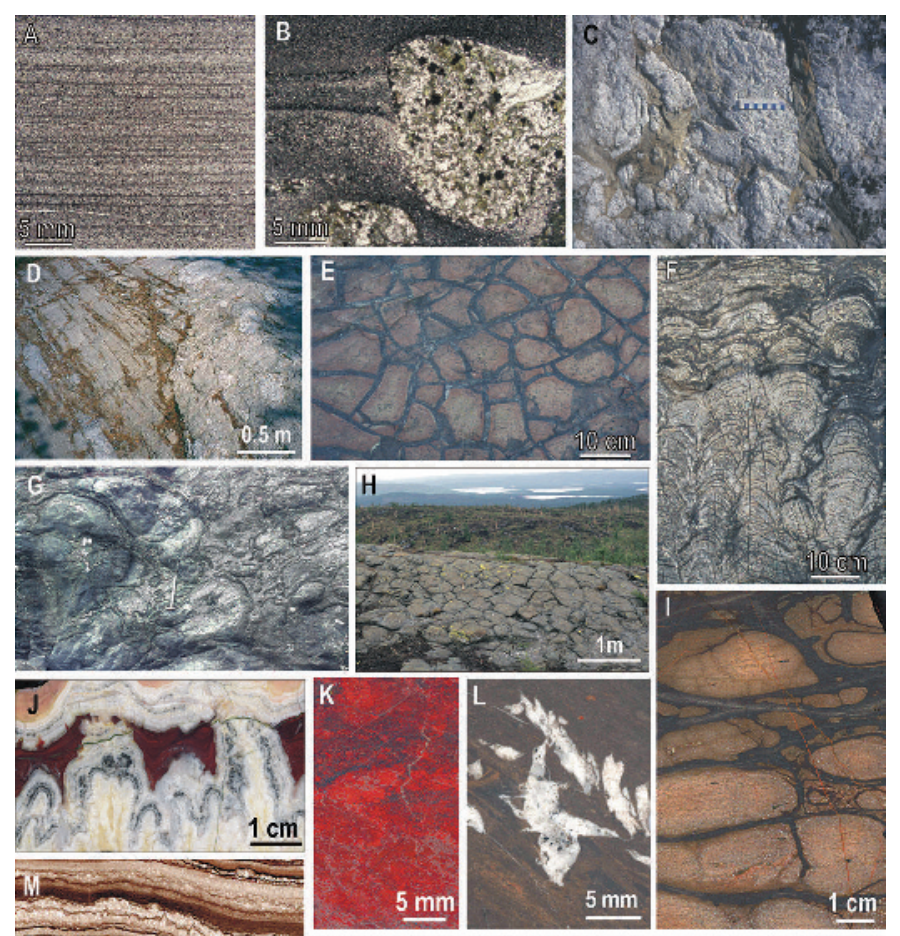

$\underline{5 \mathrm{~mm}}$

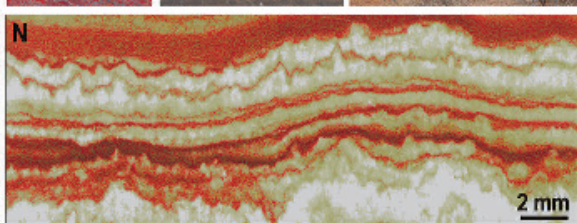

Figure 3. Rocks recording environmental events through ca. 2500-2060 Ma. Intracontinental rifting and glacial deposits from the Sarioli Group of the Pechenga and Imandra-Varzuga Greenstone Belts: (A) varves; (B) "dropstone"; (C) sand-filled cracks and fractures in Archean pegmatite recording incipient extension along the northern shoulder of the Pechenga paleorift; (D) erosional scouring at base of boulder conglomerates on Archean paragneiss (to left). Sedimentary features of Jatuli Group rocks from the Onega Basin: (E) desiccated red mudstone indicating an $\mathrm{O}_{2}$ rich atmosphere; (F) dolomitic columnar stromatolites. Volcanites of the Jatuli Group from the Pechenga Greenstone Belt: (G) slumped pillows in rift-basin lake; $(\mathrm{H})$ columnar joints in alkaline basalts; (I) magmatically oxidized dacite. Chemical sedimentary rocks of the Jatuli Group from the Pechenga Greenstone Belt and the Onega Basin: (J) hot-spring travertine; (K) jasper; dolomite-pseudomorphed; (L) rosettes of gypsum with swallow-tail twin morphology; $(M)$ sulfate nodule in former bedded evaporite; $(\mathrm{N})$ bedded evaporite with enterolithic structure.

sometime after 2450 Ma but before $2320 \mathrm{Ma}$ (Bekker et al., 2004) and about the time of the glaciation (Hannah et al., 2004). In Fennoscandia, this period was marked by intracratonic rifting and incursion of shallow-water epeiric seas with widespread deposition of terrestrial "red beds," microbial carbonates, mature clastic sediments with Fe- and Mn-oxide mineralization (Melezhik, 1984), and voluminous alkaline to tholeiitic volcanites (Fig. 3E-3I) with native copper occurrences. Active hydrothermal systems associated with subaerial, rift-bound volcanism were responsible for spectacular travertine deposits and jaspers (Melezhik and Fallick, 2001; Fig. 3J and 3K).

Why and how the GOE occurred remains unknown, but its association with widespread igneous activity is suggestive of a causal connection. Anomalously high organic carbon
$\left(\mathrm{C}_{\text {org }}\right)$ productivity and burial driving high $\mathrm{O}_{2}$ production, reflected in the Lomagundi-Jatuli $\delta^{13} \mathrm{C}$ positive isotope excursion (2330-2060 Ma; see below), originally was considered to be the cause (Baker and Fallick, 1989; Karhu and Holland, 1996), but now is known to significantly postdate the initial accumulation of atmospheric $\mathrm{O}_{2}$, as indicated by the massindependent sulfur isotope data. The lack of a global C isotope excursion between 2450-2330 Ma and the antiquity of oxygenic photosynthesizers (>2700 Ma; Brocks et al., 1999; Summons et al., 1999) suggest that the GOE may instead be related to a decline in the $\mathrm{O}_{2}$ sink associated with the oxidation of reduced volcanic and metamorphic fluids rather than an increase in the $\mathrm{O}_{2}$ source. The association of the GOE with widespread plume-related volcanism led Kump et al. (2001) to propose that mantle overturn associated with plume events at ca. 2700 and ca. 2500 Ma may have brought previously subducted, oxidized oceanic lithosphere (or perhaps banded iron formations) from the lower mantle back to the surface, increasing the average redox state of the upper mantle and the oxygen fugacity $\left(f_{\mathrm{O}_{2}}\right)$ of volcanic gases, and thus reducing the $\mathrm{O}_{2}$ sink (Holland, 1978). The ca. 2214 Ma volcanic rocks (Fig. 3G-3I) in the Pechenga Greenstone Belt have high $\mathrm{Fe}^{3+} / \mathrm{Fe}_{\text {total }}$ ratios (124 analyses average 0.37 , of which $87 \%$ are $>0.25$; Predovsky et al., 1974), which are in sharp contrast to the majority of other volcanic units (ratios $<0.25$ ). While apparently too young to be the "smoking gun" for mantle redox evolution, these rocks highlight the heterogeneity of upper mantle redox state.

The lack of an apparent trend in upper mantle redox state (Delano, 2001; Canil, 2002; Li and Lee, 2004) argues against the mantle redox hypothesis, but the required increase in $f_{\mathrm{O}_{2}}$ is small (Holland, 2002) and may be within the scatter of the data (cf. Li and Lee, 2004). In response to these concerns, Catling et al. (2001) proposed that a change in the oxidation state of the continental crust created the necessary reduction in $\mathrm{O}_{2}$ sink. Both of these hypotheses rely upon considerable Archean hydrogen loss to space to allow for the oxidation of the crust and/or mantle. Tian et al. (2005) proposed that hydrogen loss rates may have been much below the diffusion-limited rate and thus considerably lower than previously estimated, but this remains a controversial suggestion. Thus, the cause of the GOE remains unresolved and provides considerable motivation for future research on the ArcheanPaleoproterozoic transition.

\section{Abundant Marine Calcium Sulfates and Changes in Seawater Composition}

Additional evidence for the GOE in Fennoscandia includes ca. 2100 Ma rocks (Fig. 2) containing relatively abundant syngenetic barite (Grinenko et al., 1989) and pseudomorphs after Ca-sulfates. The latter are abundant in the Onega Basin (Fig. 1) and are associated with magnesite and pseudomorphed halite crystals in a 500-m-thick succession covering more than $2000 \mathrm{~km}^{2}$. They occur in varied facies: playa mudstones and fenestral stromatolitic sheets, sabkha and supratidal stromatolitic sheets, peritidal to intertidal biostromal and columnar stromatolites and variegated dolostones, and intertidal lenticular-bedded siltstone-mudstone couplets (Melezhik et al., 2000, 2005). Former Ca-sulfates occur mostly as dolomite and 
silica pseudomorphs, commonly retaining relics of primary anhydrite (a variety of single and twinned crystal forms) and as diverse nodules, nodular masses with "chicken-wire" structure, and laminites with enterolithic structure (Fig. 3L-3N).

These evaporites postdate the events leading to irreversible oxidation of terrestrial environments that began prior to 2320 $\mathrm{Ma}$, as evident by subaerial "red beds" (reviewed in Melezhik et al., 1999b). Combined, these features imply that the evaporites apparently precipitated syndepositionally from oxidized, evolved, and modified seawater (Melezhik et al., 2001), and their abundance in conjunction with those reported from elsewhere (Chandler, 1988; El Tabakh et al., 1999; Bekker and Eriksson, 2003) suggests that surface waters were oxidized and that sulfate had started to accumulate in the marine surface realm, a suggestion consistent with the sparse $\delta^{34} S$ data that exist for this interval (e.g., Strauss, 1993, 2004). Oceanic sulfate abundance remains unknown, but a sizeable sulfate reservoir as early as $2100 \mathrm{Ma}$ would contrast with the view that, prior to the Mesoproterozoic, gypsum precipitation was inhibited by a small marine sulfate reservoir and higher marine carbonate saturation (Grotzinger, 1989; Kah et al., 2004). The irregular, cyclic, secular variations of geochemical parameters known for Phanerozoic terrestrial hydrosphere and atmosphere systems (Budyko et al., 1985; Veizer, 2005) may provide a means of reconciling these conflicting views.

\section{Positive Carbon Isotope Excursion: The Lomagundi-Jatuli Paradox}

The key discovery by Schidlowski et al. (1976) of unusually enriched ${ }^{13} \mathrm{C}$ Paleoproterozoic sedimentary carbonates in the Lomagundi province presented geologists with a puzzle. It took a decade for the first realization (Baker and Fallick, 1989) and a further decade for wide international acceptance (Karhu and Holland, 1996) of the Lomagundi-Jatuli Event as one of the major perturbations of the global carbon cycle in deep time, one associated with a series of fundamental changes of Earth's surface (Fig. 4). In Fennoscandia, the excursion occurred after the glaciation and GOE, between 2330 and $2060 \mathrm{Ma}$ (Karhu, 1993). Interestingly, it is primarily recorded in what we interpret as continental rift-basin lacustrine carbonates having little to no marine influences (Melezhik et al., 1997). The carbon isotopic composition of the carbonate $\left(\delta^{13} \mathrm{C}_{\text {carb }}\right)$ values display a broad range strongly correlated with environmental setting: playa and sabkha stromatolitic dolostones are most enriched, whereas those from intertidal settings exhibit lower $\delta^{13} \mathrm{C}$ values (Melezhik et al., 2005). These facies-dependent trends suggest that the global $\delta^{13} \mathrm{C}_{\text {carb }}$ excursion was smaller than previously thought, being amplified by up to $8 \%$ by local environmental factors such as rapid expansion of stromatolite communities in shallow-water evaporative and partly restricted environments, high bioproductivity and enhanced uptake of ${ }^{12} \mathrm{C}$, and penecontemporaneous recycling of organic matter in cyanobacterial mats with the production and consequent loss of $\mathrm{CO}_{2}$ (and $\mathrm{CH}_{4}$ ?). Thus, extracting the global $\delta^{13} \mathrm{C}$ excursion from the Fennoscandian Shield data has been controversial (Karhu, 1993; Melezhik and Fallick, 1996; Shields, 1997; Melezhik et al., 1999b).

Nevertheless, the Paleoproterozoic isotopic excursion is unique in terms of its duration (although age constraints are

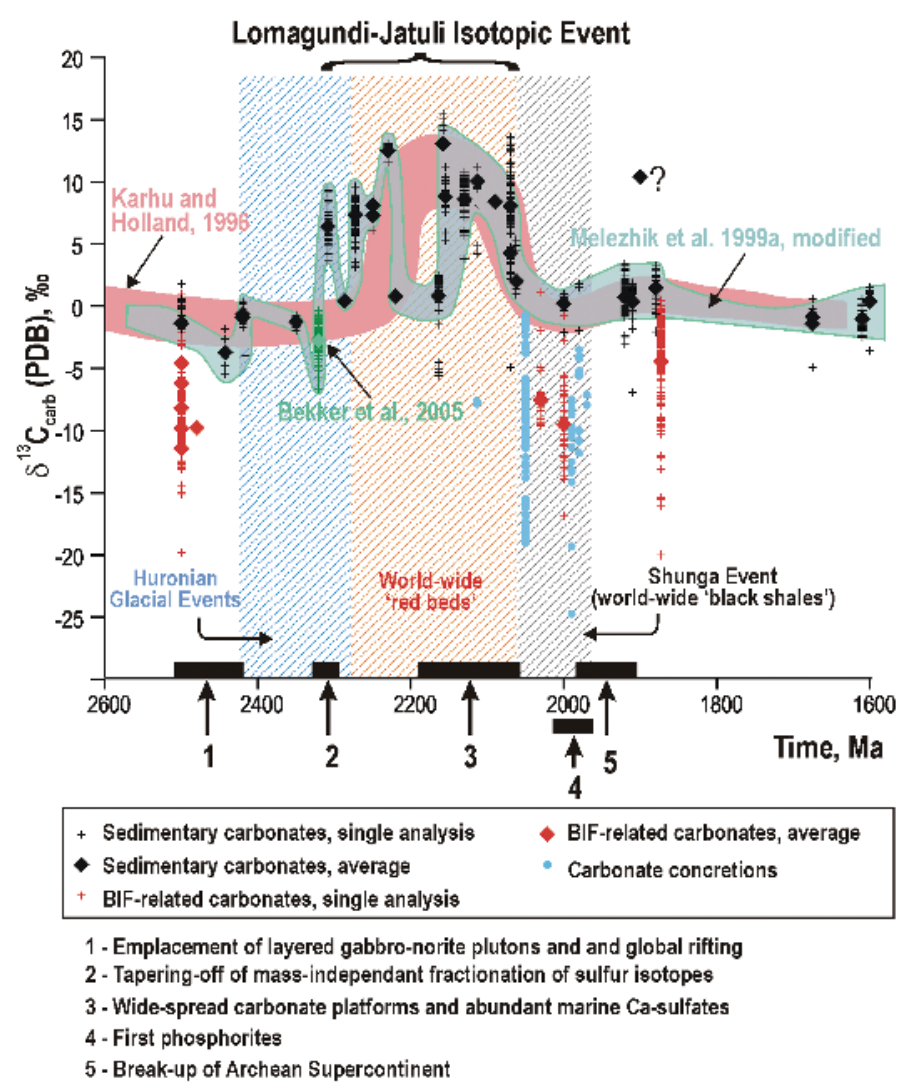

Figure 4. Paleoproterozoic $\delta^{13} \mathrm{C}_{\text {carb }}$ trends of sedimentary and diagenetic carbonates and associated phenomena (modified from Melezhik et al., 1999b, including data from Bekker et al., 2005). BIF_-banded iron formations; PDB —Peedee belemnite.

not robust, it appears to be $>300 \mathrm{Ma}$ ) and ${ }^{13} \mathrm{C}$ enrichment. $\delta^{13} \mathrm{C}$ values of purportedly synchronous deposits ranging from $+8 \%$ to $+28 \%$ (the latter interpreted as a global marine signal by Bekker et al., 2003a) have been reported from elsewhere around the world. Unlike the smooth $\delta^{13} \mathrm{C}_{\text {carb }}$ trend generally depicted, the overall positive excursion is now argued to have two or three positive shifts separated by returns to $0 \%$ (Melezhik et al., 1999b, Fig. 4) that, unlike many younger isotopic events, do not go significantly below 0\%. Furthermore, there is no geological evidence for enhanced $\mathrm{C}_{\text {org }}$ accumulation prior to or synchronous with the excursion (although we cannot exclude preservational biases). Instead, it is the termination of the excursions that is followed by formation of a vast reservoir of variably ${ }^{13} \mathrm{C}$-depleted organic material $(-45 \%$ to $-17 \%$ in the Onega Basin; see below) at a time when associated sedimentary carbonates are isotopically normal (Karhu, 1993; Melezhik et al., 1999a). Thus, determining the global timing of and regional influences on this event and identifying the mechanism(s) responsible for one of the most profound carbon isotopic excursions in earth history still represent major challenges for future research.

\section{$\mathrm{C}_{\mathrm{org}}$-Rich Rocks and Earliest Significant Oil Deposits-The Shunga Event}

Although Archean oil occurs elsewhere (e.g., Rasmussen, 2005), the most remarkable accumulation of organic matter and inferred generation of petroleum in the Paleoproterozoic 


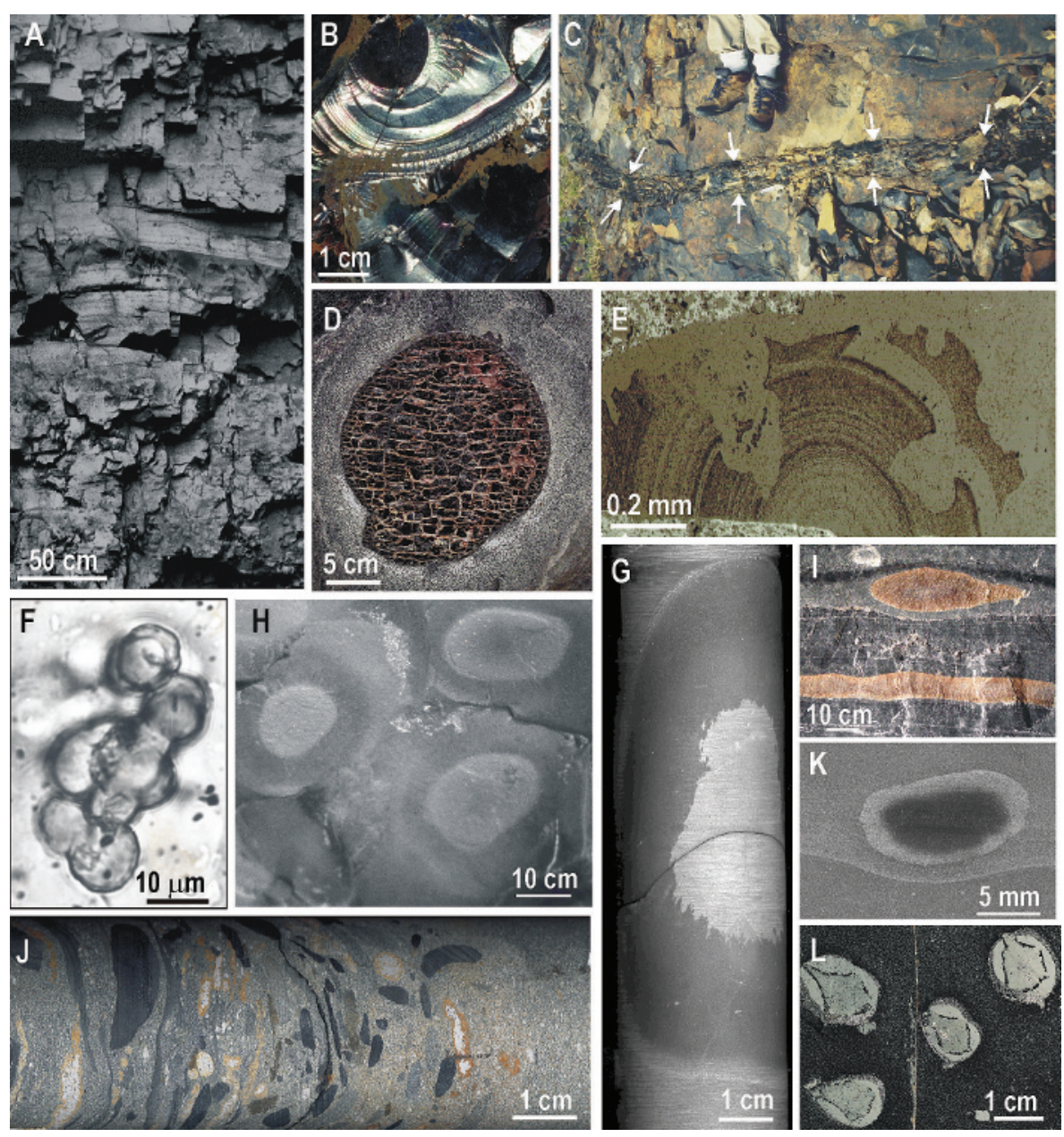

Figure 5. Rocks recording environmental events through 2060-1960 Ma. Petrified oil deposits of the Ludikovi Group from the Onega Basin: (A) semi-lustrous shungite (originally oil shale; $45 \%-75 \%$ C); (B) lustrous layered shungite (originally interbedded-trapped oil; $98.4 \% \mathrm{C}_{\text {org }}$ ); (C) pyrobitumen-filled vein (petrified oil) in $\mathrm{C}_{\text {org }}$-rich siltstone; (D) pyrobitumen clasts in lacustrine turbiditic graywacke; (E) organosiliceous rock with micron-scale concentric structure (reflected light). Microfossil from the Ludikovi Group in the Pechenga Greenstone Belt: (F) coccoidal microfossil from nonstromatolitic chert interbedded with pillow basalts. Diagenetic concretions and phosphorites of the Ludikovi Group from the Pechenga Greenstone Belt and the Onega Basin: $(\mathrm{G})$ zoned, low- $\delta^{13} \mathrm{C}$ calcitic diagenetic concretion in marine "black schist"; (H) calcite concretions in turbiditic graywacke; (I) sideritic diagenetic concretion in lacustrine turbiditic graywacke; (J) phosphorite clasts (black) in graywacke: (K) phosphorus-rich nodules in graywacke; (L) zoned sulphide concretions in "black schist."

took place in the aftermath of the ca. 2330-2060 Ma Lomagundi-Jatuli Event (Melezhik et al., 1999a, 2004). $2000 \mathrm{Ma}$ deposits rich in matured organic matter have been found in North America, Greenland, West Africa, and NW Russia (reviewed in Melezhik et al., 1999a) and represent the worldwide Shunga Event. In the Onega Basin, organic matter in unusually high $\mathrm{C}_{\text {org }}$ concentrations (up to $98 \%$; average $\sim 25 \%$ ) occurs in a 1000 m-thick sedimentary-volcanic succession covering $9000 \mathrm{~km}^{2}$. It is termed shungite, a black, noncrystalline, dense, glassy mineraloid with high semi-metallic luster and up to $>98 \mathrm{wt} \% \mathrm{C}$ (with traces of $\mathrm{N}, \mathrm{O}, \mathrm{S}$, and $\mathrm{H})$. It accumulated in a non-euxinic, brackish lagoonal setting of a volcanically active continental rift (Melezhik et al., 1999a).

Shungite occurs either in situ and stratified, as migrated organosiliceous diapirs, or as redeposited clasts (Fig. 5A-5E; Melezhik et al., 2004). In situ shungite is metamorphosed oil shale (C $<50 \%$ ) containing autochthonous kerogen residue and allochthonous organic matter ( $\mathrm{C}=50 \%-75 \%)$ and bitumen (originally liquid hydrocarbons, $\mathrm{C}>80 \%$ ). The type locality at Shunga (the most significant volume of trapped petroleum in the Onega
Basin) displays good examples of vertical and lateral migration of oil-defining cupola and diapiric bodies. These are organosiliceous rocks $\left(35 \%-75 \% \mathrm{SiO}_{2}\right.$ and $20 \%-55 \% \mathrm{C}$ ), considered to be originally gels or mud, with enigmatic concentric microstructures, abundant shrinkage cracks and cryptic fluidal textures, and brecciation caused by multiple fluidization processes. Lastly, clasts of lustrous shungite $(<0.1-20 \mathrm{~cm})$ eroded from subaerial oil spills occur in lacustrine volcaniclastic turbidites. In all occurrences, the organic matter suffered complex catagenetic and metamorphic alteration as evident by (Melezhik et al., 1999a): (1) four-modal distribution of $\mathrm{C}_{\text {org }}$ content (maxima at 5\%, 30\%, $65 \%$, and 95\%); (2) highly variable ( -45 to $-17 \%$ ) and bimodal distribution of $\delta^{13} \mathrm{C}_{\text {org }}$ (maxima at -28 and $-39 \%$ ); and (3) low H/C ratios (0.005-0.2). Abundant diagenetic carbonates associated with shungite rocks (Fig. $5 \mathrm{H}$ and 5I; $\delta^{13} \mathrm{C}_{\text {carb }}=-5$ to $-26 \%$ ) and the presence of diagenetic pyrite $\left(\delta^{34} \mathrm{~S}=-22\right.$ to $+31 \%$; Shatzky, 1990) reflect loss of organic matter via bacterial reduction of sulfate during diagenesis.

The integrated data suggest that the organic matter was most likely derived from planktonic microorganisms (it is noteworthy that peculiar microfossils [Fig. $5 \mathrm{~F}]$ in non-stromatolitic cherts associated with extensive pillow lavas have been reported; Ivanova et al., 1988), but the cause of such unprecedented worldwide accumulation of organic matter at 2000 Ma remains unknown. If the fundamental features of the biologic carbon cycle were established by 3500 Ma (Schidlowski et al., 1975; Hayes et al., 1983; Grassineau et al., 2002), why did it take until 2000 Ma for the oldest known significant accumulation of organic carbon-rich sediments and petroleum deposits? Does this reflect an episode of enhanced biological productivity in a nutrient-enriched ocean that elsewhere supported widespread euxinia? Or was productivity more modest but preservation enhanced?

\section{Fundamental Changes in the Early Diagenesis of Organic Matter}

Compilation of global data shows that, with the exception of banded iron formations, $\delta^{13} \mathrm{C}$ values of both primary and diagenetic carbonates of 
pre-Paleoproterozoic rocks cluster near $0 \pm 3 \%$ (Melezhik et al., 1999b). The end of the Lomagundi-Jatuli Event is marked by the first known appearance, and then worldwide development, of diagenetic carbonate concretions with negative $\delta^{13} \mathrm{C}_{\text {carb }}$ values (Melezhik, 1992; Melezhik et al., 1999b). These are varied (Figs. 5G-5J) and abundant in the 2000 Ma sedimentary successions and are associated with other diagenetic products, such as phosphate nodules (Fig. 5K), all of which are seemingly absent from older rocks. Thus, this first appearance of isotopically light diagenetic carbonate concretions is an important hallmark in biospheric evolution linked to the emergence of "modern-style" recycling of organic matter. Perhaps prior to $2000 \mathrm{Ma}$ fermentative methanogenesis rather than oxidation dominated early diagenetic organic matter remineralization (because of lack of $\mathrm{O}_{2}$ and $\mathrm{SO}_{4}^{2-}$ ). Escape of low $\delta^{13} \mathrm{C}$ methane from the porewaters would have prevented the development of isotopically light porewaters. This hypothesis represents another subject for future research.

Sulfur isotope data $\left(\delta^{34} S\right)$ display a narrow range around mantle values, 0\%o (e.g., Strauss, 2002). Bacterial sulfur metabolism has an early origin (ca. $3.47 \mathrm{Ga}$; Shen and Buick, 2004) and, although multiple lines of evidence of biogenicity are lacking, microbial sulfate reduction under either higher temperature and/or extremely low oceanic sulfate concentration leading to minimal isotopic fractionation has been suggested (e.g., Ohmoto and Felder, 1987; Ohmoto et al., 1993; Habicht et al., 2002). Recent data on mass-independently fractionated sulfur isotopes (Farquhar et al., 2000) suggest that photochemical dissociation of sulfur dioxide in an "oxygenfree" $\left(\mathrm{O}_{2}\right.$ partial pressure $\left.<10^{-5}\right)$ atmosphere might have dominated the global Archean sulfur cycle and enabled transfer of both oxidized and reduced sulfur compounds with distinct mass-independent isotope signatures to surface environments.

In contrast, sediments deposited during the early Paleoproterozoic contain sedimentary pyrite displaying a substantially larger isotopic fractionation $\left(\delta^{34} S_{\text {suffate-sulfide }}\right)$. The 2000 Ma successions differ markedly from older rocks by having a high abundance of various diagenetic generations of iron sulfides (Fig. 5L) with $\delta^{34} S$ values ranging between $-22 \% 0$ and $+31 \% 0$ (Melezhik et al., 1998; Shatzky, 1990). Even more negative values, as low as $-30 \%$, have been reported from the 2320 Ma Timeball Hill Formation, South Africa (Cameron, 1982; Bekker et al., 2004). Based on present understanding (e.g., Canfield, 2001), such values represent evidence for bacterial sulfate reduction and, given the absence of evidence for mass-independent sulfur isotopic fractionation in rocks younger than $2320 \mathrm{Ma}$, imply a profound change in the operational mode of the global sulfur cycle and concomitant increase in atmospheric oxygen concentration (Pavlov and Kasting, 2002). Subsequently, a rise in oceanic sulfate concentration enhanced the importance of bacterial sulfate reduction as a principal process of organic carbon and sulfur cycling in sedimentary environments. Hence, the global sulfur cycle changed into a mode quite similar to the modern world in which oxidative weathering, riverine delivery of sulfate to the ocean, and biological sulfur cycling dominate over volcanic/ hydrothermal S cycling. However, a smaller than present-day isotopic fractionation associated with bacterial sulfate reduction and subsequent pyrite formation may be consistent with an ocean low in sulfate through $2000 \mathrm{Ma}$, and probably until the Precambrian-Cambrian transition (e.g., Lyons et al., 2004). The driving forces of these changes remain to be established.

The oldest known phosphorites and phosphate concretions (Fig. 5J and 5K) are commonly associated with sulfides and organic matter in the 2000 Ma successions and reflect a critical change in the Precambrian phosphorous cycle. Although different processes have been proposed for concentrating dissolved phosphate in bottom sediments to levels required for authigenic precipitation, the most common pathway includes organic matter that carries phosphate concentrated by biological activity (Knudsen and Gunter, 2002). The association of phosphate concretions with organic matter in the $\mathrm{C}_{\text {org }}$-rich 2000 Ma sedimentary rocks is consistent with such a mechanism. However, high abundance of organic matter is probably not the only factor controlling formation of Paleoproterozoic phosphate concretions. $\mathrm{C}_{\text {org }}$-rich layers have also been found in sedimentary sequences older than $2000 \mathrm{Ma}$ (Hayes et al., 1983), but no phosphate concretions have been reported. Thus, it is possible that $2000 \mathrm{Ma}$ sediments record a major change in the diagenetic mineralization of organic matter, perhaps reflecting a substantial increase in the intensity of earlydiagenetic sulfate reduction promoted by an overlying, sulfate-enriched ocean (Canfield and Raiswell, 1999) that in turn elevated the concentration of interstitial phosphate. However, determining the factors that controlled the formation of the oldest known phosphate concretions remains an unresolved problem.

\section{QUESTIONS FOR FUTURE RESEARCH}

The Archean-Paleoproterozoic transition was a major step in the eventual establishment of the modern earth system. A relative chronology of the transition has been determined, but fundamental questions remain unanswered. (1) Why did global glaciations only occur after the Archean? (Evidence for glaciation at $2900 \mathrm{Ma}$ is restricted to South Africa; Young et al., 1998.) (2) Why did an oxygen-rich atmosphere only appear in the Proterozoic (around $2400 \mathrm{Ma}$ )? Oxygen-rich habitats existed since at least $2700 \mathrm{Ma}$. (3) What drove the Lomagundi-Jatuli Event, the oldest known positive global carbon isotope excursion? (4) What caused radical change in biogeochemical recycling of organic matter at ca. 2060 Ma? (5) Why didn't large accumulations of organic matter similar to the Shunga Event occur in the Archean? (6) How, out of this suite of biogeochemical global-scale perturbations, did the modern earth system emerge? The recently launched International Geological Correlation Programme Project 509 "Palaeoproterozic Supercontinents and Global Evolution" will be a focus for internationally coordinated research on this most interesting time period in earth history.

\section{ACKNOWLEDGMENTS}

The authors wish to thank David Des Marais, Gerry Ross, and an anonymous reviewer for their helpful comments and suggestions on the original manuscript. LRK acknowledges support from the National Aeronautics and Space Administration Astrobiology Institute.

\section{REFERENCES CITED}

Amelin, Yu.V., Heaman, L.M., and Semenov, V.S., 1995, U-Pb geochronology of layered mafic intrusions in the eastern Baltic Shield: implications for the timing and duration of Palaeoproterozoic continental rifting: Precambrian Research, v. 75, p. 31-46, doi: 10.1016/0301-9268(95)00015-W.

Anbar, A.D., and Knoll, A.H., 2002, Proterozoic ocean chemistry and evolution: A bioinorganic bridge?: Science, v. 297, p. 1137-1142, doi: 10.1126/science.1069651. 
Aspler, L.B., and Chiarenzelli, J.R., 1998, Two Neoarchean supercontinents? Evidence from the Paleoproterozoic: Sedimentary Geology, v. 120, p. 75-104, doi: 10.1016/ S0037-0738(98)00028-1.

Baker, A.J., and Fallick, A.E., 1989, Heavy carbon in two-billion-year-old marbles from Lofoten-Vesterålen Norway: Implications for the Precambrian carbon cycle: Geochimica et Cosmochimica Acta, v. 53, p. 1111-1115, doi: 10.1016/0016-7037(89)90216-0.

Balashov, Yu.A., 1996, Geochronology of Early Proterozoic rocks from the Pechenga-Varzuga structure in the Kola Peninsula: Petrology, v. 4, p. 3-25.

Bekker, A., and Eriksson, K., 2003, Palaeoproterozoic drowned carbonate platform on the southeastern margin of the Wyoming Craton: a record of the Kenorland breakup: Precambrian Research, v. 120, p. 327-363, doi: 10.1016/ S0301-9268(02)00165-1.

Bekker, A., Kaufman, A.J., Karhu, J.A., Beukes, N.J., Swart, Q.D., Coetzee, L.L., and Eriksson, K.A., 2001 Chemostratigraphy of the Paleoproterozoic Duitschland Formation, South Africa; implications for coupled climate change and carbon cycling: American Journal of Science, v. 301, p. 261-285.

Bekker, A., Karhu, J.A., Eriksson, K.A., and Kaufman, A.J., 2003a, Chemostratigraphy of Palaeoproterozoic carbonate successions of the Wyoming Craton: Tectonic forcing of biogeochemical change?: Precambrian Research, v. 120, p. 279-325, doi: 10.1016/S0301-9268(02)00164-X.

Bekker, A., Sial, A.N., Karhu, J.A., Ferreira, V.P., Noce, C.M. Kaufman, A.J., Romano, A.W., and Pimentel, M.M., 2003b, Chemostratigraphy of carbonates from Minas Supergroup, Quadrilátero Ferrífero (Iron Quadrangle), Brazil: a stratigraphic record of Early Proterozoic atmospheric, biogeochemical and climatic change: American Journal of Science v. 330 , p. $865-904$.

Bekker, A., Holland, H.D., Wang, P.L., Rumble, D., III, Stein H.J., Hannah, J.L., Coetzee, L.L., and Beukes, N.J., 2004, Dating the rise of atmospheric oxygen: Nature, v. 427 p. 117-120, doi: 10.1038/nature02260.

Bekker, A., Kaufman, A.J., Karhu, J.A., and Eriksson, K.A., 2005, Evidence for Paleoproterozoic cap carbonates in North America: Precambrian Research, v. 137, p. 167-206, doi: 10.1016/j.precamres.2005.03.009.

Brocks, J.J., Logan, G.A., Buick, R., and Summons, R.E., 1999, Archean molecular fossils and the rise of eukaryotes: Science, v. 285, p. 1033-1036, doi: 10.1126/science. 285.5430.1033.

Budyko, M.I., Ronov, A.B., and Yanshin, A.L., 1985, History of the atmosphere: Leningrad, Gidrometeooizdat, 208 p. (in Russian).

Cameron, E.M., 1982, Sulphate and sulphate reduction in early Precambrian oceans: Nature, v. 296, p. 145-148, doi: 10.1038/296145a0

Canfield, D.E., 1998, A new model for Proterozoic ocean chemistry: Nature, v. 396, p. 450-453, doi: 10.1038/24839.

Canfield, D.E., 2001, Biogeochemistry of sulfur isotopes, in Valley, J.W. and Cole, D.R., eds., Stable isotope geochemistry: Reviews in Mineralogy and Geochemistry, v. 43, p. 607-636.

Canfield, D.E., and Raiswell, R., 1999, The evolution of the sulfur cycle: American Journal of Science, v. 299, p. 697-723.

Canil, D., 2002, Vanadium in peridotites, mantle redox and tectonic environments: Archean to present: Earth and Planetary Science Letters, v. 195, p. 75-90, doi: 10.1016/ S0012-821X(01)00582-9.

Catling, D., Zahnle, K.J., and McKay, C.P., 2001, Biogenic methane, hydrogen escape, and the irreversible oxidation of early Earth: Science, v. 293, p. 839-843, doi: 10.1126/science. 1061976

Chandler, F.W., 1988, Diagenesis of sabkha-related, sulphate nodules in the Early Proterozoic Gordon Lake Formation, Ontario, Canada: Carbonates and Evaporites, v. 3, p. 75-94.

Cox, K.G., 1989, The role of mantle plumes in the development of continental drainage patterns: Nature, v. 342, p. 873-877, doi: 10.1038/342873a0.

Delano, J.W., 2001, Redox history of the Earth's interior since 3900 Ma: Implications for prebiotic molecules:
Origins of Life and Evolution of the Biosphere, v. 31, p. 311341, doi: 10.1023/A:1011895600380.

Dessert, C., Dupré, B., François, L.M., Schott, J., Gaillardet, J., Chakrapani, G.J., and Bajpai, S., 2001, Erosion of Deccan Traps determined by river geochemistry: Impact on the global climate and ${ }^{87} \mathrm{Sr} /{ }^{86} \mathrm{Sr}$ ratio of seawater: Earth and Planetary Science Letters, v. 188, p. 459-474, doi: 10.1016/ S0012-821X(01)00317-X.

El Tabakh, M., Grey, C., Pirajno, F., and Schreiber, B.C., 1999, Pseudomorphs after evaporitic minerals interbedded with 2.2 Ga stromatolites of the Yerrida basin Western Australia: Origin and significance: Geology, v. 27 p. 871-874, doi: 10.1130/0091-7613(1999)027<0871: PAEMIW $>2.3$.CO;2.

Evans, D.A.D., 2003, A fundamental PrecambrianPhanerozoic shift in Earth's glacial style?: Tectonophysics, v. 375, p. 353-385, doi: 10.1016/S0040-1951(03)00345-7.

Farquhar, J., Bao, H., and Thiemens, M., 2000, Atmospheric influence of Earth's earliest sulfur cycle: Science, v. 289, p. 756-758, doi: 10.1126/science.289.5480.756.

Grassineau, N.V., Nisbet, E.G., Fowler, C.M.R., Bickle, M.J., Lowry, D., Chapman, H.J., Mattey, D.P., Abell, P. Young J, and Martin, A, 2002, Stable isotopes in the Archaean Belingwe Belt, Zimbabwe; evidence for a diverse microbial mat ecology, in Fowler, C.M.R., Ebinger, C.J. and Hawkesworth, C., eds., The early Earth; physical, chemical and biological development: London, Geological Society Special Publication 199, p. 309-328.

Grinenko, L.N., Melezhik, V.A., and Fetisova, O.A., 1989, The first discovery of sedimentary barite in Precambrian deposits of the Baltic Shield: Communications of the USSR Academy of Sciences, v. 304, p. 1453-1455.

Grotzinger, J.P., 1989, Facies and evolution of Precambrian carbonate depositional systems; emergence of the modern platform archetype, in Crevello, P.D., Wilson, J.J., Sarg, J.F. and Read, F. eds., Controls on carbonate platform and basin development: Special Publication of Society of Economic Paleontologists and Mineralogists: Tulsa, Oklahoma, v. 44, p. 79-106.

Habicht, K.S., Gade, M. Thamdrup, B., Berg, P., and Canfield, D.E., 2002, A calibration of sulfate levels in the Archean Ocean: Science, v. 298, p. 2372-2374, doi: 10.1126/science. 1078265 .

Hannah, J.L., Bekker, A., Stein, H.J., Markey, R.J., and Holland, H.D., 2004, Primitive Os and 2316 Ma age for marine shale: Implications for Paleoproterozoic glacia events and the rise of atmospheric oxygen: Earth and Planetary Science Letters, v. 225, p. 43-52, doi: 10.1016/ j.epsl.2004.06.013.

Hanski, E.J., 1992, Petrology of the Pechenga ferropicrites and cogenetic Ni-bearing gabbro-wehrlite intrusions, Kola Peninsula, Russia: Geological Survey of Finland Bulletin v. 367,192 p.

Hayes, J.M., Kaplan, I.R., and Wedeking, K.W., 1983, Precambrian organic geochemistry, preservation of the record, in Schopf, J.W., ed., Earth's earliest biosphere: Its origin and evolution: Princeton, New Jersey, Princeton University Press, p. 93-135.

Heaman, L.M., 1997, Global mafic volcanism at 2.45 Ga: Remnants of an ancient large igneous province? Geology, v. 25, p. 299-302, doi: 10.1130/00917613(1997)025<0299:GMMAGR>2.3.CO;2.

Holland, H.D., 1978, The chemistry of the atmosphere and oceans: New York, J. Wiley and Sons, 351 p.

Holland, H.D., 2002, Volcanic gases, black smokers, and the great oxidation event: Geochimica et Cosmochimica Acta, v. 66, p. 3811-3826, doi: 10.1016/S00167037(02)00950-X

Ivanova, L.V., Chapina, O.S., and Melezhik, V.A., 1988, Discovery of coccoidal microfossils in early Precambrian metamorphosed cherts: Communications of the USSR Academy of Sciences, v. 303, p. 210-211.

Kah, L.C., Lyons, T.W., and Frank, T.D., 2004, Low marine sulphate and protracted oxygenation of the Proterozoic biosphere: Nature, v. 431, p. 834-838, doi: 10.1038/ nature02974

Karhu, J.A., 1993, Palaeoproterozoic evolution of the carbon isotope ratios of sedimentary carbonates in the Fennoscandian Shield: Geological Survey of Finland Bulletin, v. 371, p. 1-87.
Karhu, J.A., and Holland, H.D., 1996, Carbon isotopes and rise of atmospheric oxygen: Geology, v. 24 , p. 867-879, doi: 10.1130/0091-7613(1996)024<0867: CIATRO $>2.3 . \mathrm{CO} ; 2$

Knudsen, A.C., and Gunter, M.E., 2002, Sedimentary Phosphates-An example: Phosphoria Formation, southeastern Idaho, U.S.A., in Kohn, M.J., Rakovan, J., and Hughes, J., eds., Reviews in Mineralogy and Geochemistry: Phosphates: Geochemical, geobiological, and materials importance, v. 48, p. 363-389.

Kump, L.R., Kasting, J.F., and Barley, M.E., 2001 Rise of atmospheric oxygen and the "upside-down" mantle: Geochemistry, Geophysics, Geosystems, v. 2, 2000GC000114.

Li, Z.-X.A., and Lee, C.-T.A., 2004, The constancy of upper mantle $\mathrm{fO}_{2}$ through time inferred from $\mathrm{V} / \mathrm{Cs}$ ratios in basalts: Earth and Planetary Science Letters, v. 228, p. 483-493, doi: 10.1016/j.epsl.2004.10.006

Lyons, T.W., Kah, L.C., and Gellatly, A.M., 2004, The Precambrian sulfur isotope record of evolving atmospheric oxygen, in Eriksson, P.G. et al., eds., The Precambrian Earth: Tempos and events: Amsterdam, Elsevier, Developments in Precambrian Geology, v. 12, p. 421-439.

Marmo, J.S., and Ojakangas, R.W., 1984, Lower Proterozoic glaciogenic deposits, eastern Finland: Geological Society of America Bulletin, v. 95, p. 1055-1062, doi: 10.1130/00167606(1984)95<1055:LPGDEF>2.0.CO;2.

Melezhik, V.A., 1984, The first discovery of Precambrian manganite-bearing metasedimentary rocks on the Kola Peninsula and their metallogenetic significance:

Communications of the USSR Academy of Sciences, v. 274, p. 50-52.

Melezhik, V.A., 1992, Palaeoproterozoic Sedimentary and Rock-Forming Basins of the Fennoscandian Shield: Leningrad, Nauka, 258 p. (in Russian).

Melezhik, V.A., and Fallick, A.E., 1996, A widespread positive $\delta^{13} \mathrm{C}_{\text {cart }}$ anomaly at around $2.33-2.06 \mathrm{Ga}$ on the Fennoscandian Shield: A paradox?: Terra Nova, v. 8, p. 141-157.

Melezhik, V.A., and Fallick, A.E., 2001, Palaeoproterozoic travertines of volcanic affiliation from a ${ }^{13} \mathrm{C}$-rich lake environment: Chemical Geology, v. 173, p. 293-312, doi: 10.1016/S0009-2541(00)00281-3.

Melezhik, V.A., Fallick, A.E., Makarikhin, V.V., and Lyubtsov, V.V. 1997, Links between Palaeoproterozoic palaeogeography and rise and decline of stromatolites: Fennoscandian Shield: Precambrian Research, v. 82, p. 311-348, doi: 10.1016/S0301-9268(96)00061-7.

Melezhik, V.A., Grinenko, L.N., and Fallick, A.E., 1998 2000-Ma sulphide concretions from the 'Productive' Formation of the Pechenga Greenstone Belt, NW Russia: genetic history based on morphological and isotopic evidence: Chemical Geology, v. 148, p. 61-94, doi: 10.1016/ S0009-2541(98)00021-7.

Melezhik, V.A., Fallick, A.E, Filippov, M.M., and Larsen, O., 1999a, Karelian shungite-an indication of 2000 Ma-year-old metamorphosed oil-shale and generation of petroleum: geology, lithology and geochemistry: EarthScience Reviews, v. 47, p. 1-40, doi: 10.1016/S00128252(99)00027-6.

Melezhik, V.A., Fallick, A.E., Medvedev, P.V., and Makarikhin, V.V., 1999b, Extreme ${ }^{13} \mathrm{C}$ enrichment in ca. 2.0 Ga magnesite-stromatolite-dolomite-'red beds' association in a global context: a case for the world-wide signal enhanced by a local environment: Earth-Science Reviews, v. 48, p. 71-120, doi: 10.1016/S0012-8252(99)00044-6.

Melezhik, V.A., Fallick, A.E., Medvedev, P.V., and Makarikhin, V.V., 2000, Palaeoproterozoic magnesite-stromatolite-dolostone-'red bed' association, Russian Karelia: palaeoenvironmental constraints on the $2.0 \mathrm{Ga}$ positive carbon isotope shift: Norsk Geologisk Tidsskrift, v. 80 , p. 163-186, doi: 10.1080/002919600433724.

Melezhik, V.A., Fallick, A.E., Medvedev, P.V., and Makarikhin, V.V., 2001, Palaeoproterozoic magnesite: lithological and isotopic evidence for playa/sabkha environ ments: Sedimentology, v. 48, p. 379-397, doi: 10.1046/ j.1365-3091.2001.00369.x.

Melezhik, V.A., Filippov, M.M., and Romashkin, A.E., 2004, A giant Palaeoproterozoic deposit of shungite in NW Russia: genesis and practical applications: Ore Geology Reviews, v. 24 , p. $135-154$, doi: 10.1016/j.oregeorev.2003.08.003. 
Melezhik, V.A., Fallick, A.E., Rychanchik, D.V., and Kuznetsov, A.B., 2005, Palaeoproterozoic evaporites in Fennoscandia: implications for seawater sulphate, $\delta^{13} \mathrm{C}$ excursions and the rise of atmospheric oxygen: Terra Nova, v. 17, p. 141-148, doi: 10.1111/j.1365-3121.2005.00600.x.

Mertanen, S., Halls, H.C., Vuollo, J.L., Pesonen, L.J., and Stepanov, V.S., 1999, Paleomagnetism of 2.44 Ga mafic dykes in Russian Karelia, eastern Fennoscandian Shieldimplications for continental reconstructions: Precambrian Research, v. 98, p. 197-221, doi: 10.1016/S0301-

9268(99)00050-9.

Ohmoto, H., and Felder, R.P., 1987, Bacterial activity in the warmer, sulphate-bearing, Archaean oceans: Nature, v. 328 p. 244-246, doi: 10.1038/328244a0

Ohmoto, H., Kakegawa, T., and Lowe, D. R, 1993, 3.4-billion-year-old biogenic pyrites from Barberton, South Africa: Sulphur isotope evidence: Science, v. 267, p. 555-557.

Pavlov, A.A., and Kasting, J.F., 2002, Mass-independent fractionation of sulphur isotopes in Archaean sediments: strong evidence for an anoxic Archaean atmosphere: Astrobiology, v. 2, p. 27-41, doi: 10.1089/153110702753621321.

Pickard, A.L., 2003, SHRIMP U-Pb zircon ages for the Palaeoproterozoic Kuruman Iron Formation, Northern Cape Province, South Africa: evidence for simultaneous BIF deposition on Kaapvaal and Pilbara cratons: Precambrian Research, v. 125, p. 275-315, doi: 10.1016/S03019268(03)00113-X

Poulton, S.W., Frallk, P.W., and Canfield, D.E., 2004, The transition to a sulphidic ocean $\sim 1.84$ billion years ago: Nature, v. 431,p. 173-177, doi: 10.1038/nature02912.

Predovsky, A.A., Fedotov, G.A., and Akhmedov, A.M., 1974 Geochemistry of the Pechenga Complex: Leningrad, Nauka, 139 p. (in Russian).

Rasmussen, B., 2005, Evidence for pervasive petroleum generation and migration in 3.2 and 2.6 Ga shales: Geology, v. 33 , p. $497-500$, doi: $10.1130 / G 21316.1$.
Schidlowski, M., Eichmann, R., and Junge, C.E., 1975 , Precambrian sedimentary carbonates: carbon and oxygen isotope geochemistry and implications for the terrestrial oxygen budget: Precambrian Research, v. 2, p. 1-69, doi: 10.1016/0301-9268(75)90018-2.

Schidlowski, M., Eichmann, R., and Junge, C.E., 1976 Carbon isotope geochemistry of the Precambrian Lomagundi carbonate province, Rhodesia: Geochimica et Cosmochimica Acta, v. 40, p. 449-455, doi: $10.1016 / 0016$ 7037(76)90010-7.

Shatzky, G.V., 1990, Isotope composition of sulphides from the Zazhogino shungite deposit: Lithology and Mineral Deposits, v. 1, p. 20-28.

Shen, Y., and Buick, R., 2004, The antiquity of microbia sulfate reduction: Earth-Science Reviews, v. 64, p. 243-272, doi: 10.1016/S0012-8252(03)00054-0.

Shields, G., 1997, A widespread positive $\delta^{13} \mathrm{C}$ anomaly at around 2.33-2.06 Ga on the Fennoscandian ShieldComment: Terra Nova, v. 9, p. 218-222, doi: 10.1046/ j.1365-3121.1997.d01-37.x.

Strauss, H., 1993, The sulphur isotopic record of Precambrian sulphates: new data and a critical evaluation of the existing record: Precambrian Research, v. 63, p. 225 246, doi: 10.1016/0301-9268(93)90035-Z.

Strauss, H., 2002, The isotopic composition of Precambrian sulphides-seawater chemistry and biological evolution: Special Publications of the International Association of Sedimentologists, v. 33, p. 67-105.

Strauss, H., 2004, 4 Ga of seawater evolution; evidence from the sulfur isotopic composition of sulfate, in Amend, J.P., Edwards, K. and Lyons, T.W. eds., Sulfur biogeochemistry — past and present: Geological Society of America Special Paper 379, p. 195-202.

Summons, R.E., Jahnke, L.L., Logan, G.A., and Hope, J.M 1999, 2-Methylhopanoids as biomarkers for cyanobacteria oxygenic photosynthesis: Nature, v. 400, p. 554-557, doi: 10.1038/23005.

Taylor, A.S., and Lasaga, A.C. 1999, The role of basalt weathering in the $\mathrm{Sr}$ isotope budget of the oceans: Chemical Geology, v. 161, p. 199-214, doi: 10.1016/S0009 2541(99)00087-X.

Tian, F., Toon, O.B., Pavlov, A.A., and De Sterck, H., 2005 , A hydrogen-rich early Earth atmosphere: Science, v. 308, p. 1014-1017, doi: 10.1126/science. 1106983.

Veizer, J., 2005, Celestial climate driver: a perspective from four billion years of the carbon cycle: Geoscience Canada, v. 32, p. 3-28.

Vogel, D.C., Vuollo, J.I., Alapieti, T.T., and James, R.S. 1998, Tectonic, stratigraphic, and geochemical comparison between ca. 2500-2440 Ma mafic igneous events in the Canadian and Fennoscandian Shields: Precambrian Research, v. 92, p. 89-116, doi: 10.1016/S03019268(98)00073-4.

Williams, H., Hoffman, P.F., Lewry, J.F., and James, N.P. 1991, Anatomy of North America: thematic geologic portraits of the continent: Tectonophysics, v. 187, p. 117-134, doi: 10.1016/0040-1951(91)90416-P.

Young, G.M., von Brun, V., Gold, D.J.C., and Minter, W.E.L., 1998, Earth's oldest reported glaciation: Physical and chemical evidence from the Archean Mozaan Group ( 2.9 Ga) of South Africa: Journal of Geology, v. 106, p. 523-538.

Young, G.M., Long, D.G.F., Fedo, C.M., and Nesbitt, H.W., 2001, Paleoproterozoic Huronian basin; product of a Wilson cycle punctuated by glaciations and a meteorite impact: Sedimentary Geology, v. 141-142, p. 233-254, doi: 10.1016/S0037-0738(01)00076-8.

Manuscript received 23 June 2005; accepted 31 August 2005.

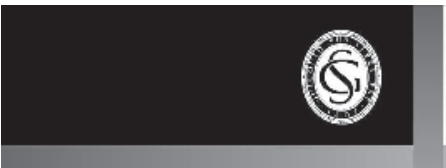

\section{New book titles from the Geological Society Publishing House}

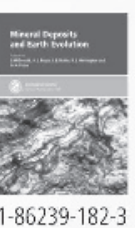

ISBN 1-86239-182-3

- September 2005 - 280 pages $\bullet$ Hardback

-Prices: List: $\mathrm{f} 75.00 / \mathrm{US} \$ 135.00$

GSL: $\mathbf{£ 3 7 . 5 0 / U S \$ 6 8 . 0 0}$ AAPG/SEPM/GSA/RAS/EFG/PESGB: £45.00/US\$81.00

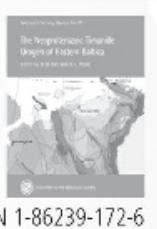

-ISBN 1-86239-172-6

- January $2005 \bullet 260$ pages $\bullet$ Hardback

-Prices: List: $£ 90.00 /$ US\$162.00

GSL: $£ 45.00 / U S \$ 81.00$

AAPG/SEPM/GSA/RAS/EFG/PESGB: f54.00/US\$98.00

\section{- Special Publication 248}

\section{Mineral Deposits and Earth Evolution}

Edited by 1. McDonald, A. J. Boyce, I. B. Butler, R. J. Herrington and D. A. Polya

Mineral deposits are not only primary sources of wealth generation, but also act as windows through which to view the evolution and interrelationships of the Earth system. Deposits formed throughout the last 3.8 billion years of the Earth's history preserve key evidence with which to test fundamental questions about the evolution of the Earth. These include: the nature of early magmatic and tectonic processes, supercontinent reconstructions, the state of the atmosphere and hydrosphere with time, and the emergence and development of life. The interlinking processes that form mineral deposits have always sat at the heart of the Earth system and the potential for using deposits as tools to understand that evolving system over geological time is increasingly recognized. This volume contains research aimed both at understanding the origins of mineral deposits and at using mineral deposits as tools to explore different long-term Earth processes.

\section{- Memoir 30}

\section{The Neoproterozoic Timanide Orogen of Eastern Baltica}

\section{Edited by D. Gee and V. Pease}

The Neoproterozoic Timanide Orogen of eastern Baltica extends from the high Arctic to the southern Ural Mountains and represents significant crustal growth of the northeastern European continental margin in the late Neoproterozoic. This volume, a co-operation between Western European and Russian scientists within the framework of the European Science Foundation's EUROPROBE programme, provides a comprehensive overview of the orogen and represents a new synthesis of Timanian Orogeny. It includes: the pre-Timanian passive margin deposits of the northern and northeastern flank of the East European Craton; the magmatic, metamorphic and structural evolution of the orogen across the Timan Mountain and Pechora Basin regions to the Ural Mountains; the post-Timanian platform successions, important for interpreting the timing of orogeny and the return to an early Palaeozoic passive margin setting; and the extension of the orogen northwards to Novaya Zemlya.

Please order from the AAPG: Inside North, Central or South America please order from: http://bookstore.aapg.org or AAPG Bookstore, P0 Box 979, Tulsa, OK 74101-0979, USA Save time: 8am to 4pm (CST) USA \& Canada: 1-800-364-AAPG (2274) International: +1-918-584 2555 (Please have your member number ready, along with your credit card and catalog order numbers) Fax (USA \& Canada): 1-800-898-2274 Fax (International): +1-918-560-2652 Email: bookstore@apap.org 